\title{
Recombinant IL1-RA in the early phase of systemic onset JIA: before the onset of arthritis
}

\author{
SJ Vastert ${ }^{1 *}$, W De Jager ${ }^{1}$, BJ Noordman ${ }^{1}$, D Holzinger ${ }^{2}$, W Kuis ${ }^{1}$, BJ Prakken ${ }^{1}$, NM Wulffraat ${ }^{1}$ \\ From 18th Pediatric Rheumatology European Society (PReS) Congress \\ Bruges, Belgium. 14-18 September 2011
}

\section{Background}

Systemic Onset Juvenile Idiopathic Arthritis (SoJIA) is characterized by systemic inflammation besides arthritis. SoJIA has a broad differential diagnosis. In a minority of SoJIA patients, it takes time (weeks to months) before arthritis develops. These cases are challenging for clinicians, as is the question how and when to treat these patients.

\section{Aim}

to identify SoJIA patients before the onset of arthritis and to evaluate treatment with recombinant IL-1RA (Anakinra) in these 'suspected SoJIA' patients.

\section{Methods}

We characterized the systemic inflammation in 5 'suspected SoJIA' patients and compared them to our cohort of known SoJIA patients. These 5 patients were thoroughly checked for alternative diagnoses by extensive microbial analysis (PCR, cultures), radiological evaluation (including $\mathrm{CT}$ and/or PET scans) and genetic testing where appropriate. Moreover, bonemarrow aspirates were performed to rule out leukemia and haemophagocytosis.

Biochemical and immunological parameters of disease activity (ESR, CRP, Ferritin) as well as newly developed biomarkers for SoJIA (cytokine profiles (IL-18), MRP's, NK cell numbers, phenotype and lytic function) were assessed at onset of disease and during treatment with Anakinra.

\section{Results}

The 5 'suspected SoJIA' patients were clinically and immunologically very similar to our cohort of SoJIA

* Correspondence: b.vastert@umcutrecht.n

${ }^{1}$ Pediatric Immunology, University Medical Center Utrecht, The Netherlands Full list of author information is available at the end of the article patients (table 1) at time of their diagnosis. We started Anakinra (dose $2 \mathrm{mg} / \mathrm{kg} /$ day) in these patients and prospectively followed them for 10 months (5-12) months. All 5 patients showed beneficial responses to Anakinra, with fast resolution of inflammation and improved NK cell function.

\section{Conclusion}

Here we show that, making use of recently developed biomarkers, 'suspected SoJIA'

patients can be identified very early in their diseasecourse, before the development of arthritis. These patients show a similar beneficial clinical response to treatment with recombinant IL-1RA as our cohort of newly diagnosed SoJIA patients. Our data support the idea of early treatment with recombinant IL-1RA in (suspected) SoJIA patients.

Table 1

\begin{tabular}{lll}
\hline Disease mark & $\begin{array}{l}\text { Suspected SoJIA patients } \\
\text { (without arthritis, } \mathbf{n = 5})\end{array}$ & $\begin{array}{l}\text { SoJIA cohort } \\
\text { Utrecht }(\mathbf{n}=15)\end{array}$ \\
\hline Spiking fever & $5 / 5$ & $15 / 15$ \\
Exanthema & $2 / 5$ & $12 / 15$ \\
Arthritis & $0 / 5$ & $15 / 15$ \\
CRP (mg/L) & $112 \pm 13$ & $209 \pm 18$ \\
BSE (mm/hr) & $128 \pm 26$ & $127 \pm 34$ \\
Ferritin (ug/L) & $937 \pm 1118$ & $2405 \pm 3855$ \\
MRP8/14 (U/L) & $38490 \pm 23077$ & $45185 \pm 37260$ \\
IL-18 plasma & $3.6 \pm 1.7$ & $8.2 \pm 9.0$ \\
(ng/L) & & \\
Abs. NK cell & $0.096 \pm 0.114$ & $0.092 \pm 0.132$ \\
$\left(x 10^{9} /\right.$ L) & & \\
NK cell function & $4.9 \pm 3.7$ & \\
(\% killing) & & \\
\hline
\end{tabular}




\title{
Author details
}

${ }^{1}$ Pediatric Immunology, University Medical Center Utrecht, The Netherlands.

${ }^{2}$ Institute of Immunology, University Hospital Münster, Münster, Germany.

Published: 14 September 2011

\author{
doi:10.1186/1546-0096-9-S1-O6 \\ Cite this article as: Vastert et al: Recombinant IL1-RA in the early phase \\ of systemic onset JIA: before the onset of arthritis. Pediatric \\ Rheumatology 2011 9(Suppl 1):O6.
}

Submit your next manuscript to BioMed Central and take full advantage of:

- Convenient online submission

- Thorough peer review

- No space constraints or color figure charges

- Immediate publication on acceptance

- Inclusion in PubMed, CAS, Scopus and Google Scholar

- Research which is freely available for redistribution 